\title{
ANALYSIS OF THE PREVALENCE OF INSOMNIA IN THE ADULT POPULATION OF SÃO JOSÉ DO RIO PRETO, BRAZIL
}

\author{
Nely Silvia Aragão de Marchi', Rubens Reimão², \\ Waldir Antonio Tognola3, José Antonio Cordeiro 4
}

\begin{abstract}
Objective: To establish the prevalence of insomnia in the adult urban population of São José do Rio Preto, Brazil and correlate it with the demographic data. Method: We evaluated 1105 individuals in to guarantee an error margin of $3 \%$ and a confidence level of $95 \%$ using a structured questionnaire and following the DSM-IV and DSM-III-R criteria, in the period from January 10 to February 282001 . Results: We encountered a prevalence of $32 \%$ of insomnia, which was most commonly seen in women, single people, from the lower economical brackets, with a low level of schooling and it was less associated with younger adults (18-31 year-olds). Conclusion: Our findings indicate that the prevalence of insomnia in the adult population of São José do Rio Preto is comparable with other countries such as the USA and those of Europe and also with other cities in Brazil.
\end{abstract}

KEY WORDS: insomnia; epidemiology, prevalence.

\begin{abstract}
Análise da prevalência da insônia na população adulta de São José do Rio Preto, Brasil
RESUMO - Objetivo: Estabelecer a prevalência da insônia na população adulta urbana de São José do Rio Preto e correlacioná-la com os dados demográficos. Método: Avaliamos 1105 indivíduos em função de um erro de $3 \%$ e nível de confiança de $95 \%$, usando um questionário estruturado e seguindo os critérios do DSM-IV e DSM-III-R, no período de 10/01 a 28/02/01. Resultados: Encontramos prevalência de 32\% de insônia, sendo esta mais associada ao sexo feminino, aos não unidos, classes econômicas $D / E$, baixo nível de escolaridade e menos associada aos mais jovens (18-31 anos). Conclusão: Nossos achados indicam que a prevalência da insônia da população adulta de São José do Rio Preto é comparável a de outros países da América do Norte, Europa e também com outras cidades do Brasil.
\end{abstract}

PALAVRAS-CHAVE: insônia, epidemiologia, prevalência.

Insomnia is a symptom that can be defined as difficulty in beginning and/or maintaining sleep, the presence of non-restoring sleep, that is, insufficient sleep to maintain a good quality of alertness and physical and mental well-being during the day, with consequent impairment in the performance of daily activities ${ }^{1}$. Among all sleep disorders insomnia is the most common ${ }^{2}$. Whilst cultures vary in their perception and reporting of sleeping problems, the human physiology is presumably similar all around the world. To respect different cultures and to reconcile them with objective findings is one of the challenges that researchers in sleep face, in an attempt to optimize the management of insomnia ${ }^{3}$.

We live in a society of excesses, we work more hours, more days and frequently, in more than one job. Not only do we work much, but we also enjoy ourselves much, going to restaurants and nightclubs and with all-night TV and Internet. We sleep $25 \%$ less than our ancestors of one century ago and there is nothing that indicates that they required more sleep than we do or that we need less than they $\mathrm{did}^{4}$.

Insomnia is implicated in an increase in automotive accidents, absenteeism, errors at work and lower achievement at school ${ }^{3}$. Despite of having a high prevalence and although it is a common cause in primary health services, it is rarely the principal complaint in a doctor's appointment ${ }^{4}$. Considering the extent of the problem of insomnia, we surveyed in the adult urban population of São José do Rio Preto with the objective of establishing the

${ }^{1}$ Ph.D., Neurology Department, Medical School of São José do Rio Preto, São José do Rio Preto SP, Brazil; ${ }^{2}$ Ph.D., Professor Clinical Neurology, Hospital das Clínicas, Medical School, University of São Paulo; ${ }^{3}$ Ph.D., Professor Neurology Department, Medical School, São José do Rio Preto; ${ }^{4}$ Ph.D., Professor Epidemiology Department, Medical School, São José do Rio Preto.

Received 27 November 2003, received in final form 29 March 2004. Accepted 22 May 2004.

Dra. Nely S. Aragão de Marchi - Rua Francisco Gigliotti 437 - 15091-280 São José do Rio Preto SP - Brasil. 
prevalence of insomnia and correlating this with the demographic data.

\section{METHOD}

The research was performed in the city of São José do Rio Preto which is located in the Northwest of São Paulo State, Brazil, with a population of 360000 inhabitants 5 . The city was split in 5 regions according to the map of the administrative regions and streets and houses were randomly chosen (drawn by chance). A structured questionnaire was applied in an interview with any adult who answered the door. The calculated sample size was of 1105 individuals to guarantee an error margin of $3 \%$ and a confidence level of $95 \%{ }^{6}$. The research project was approved by the Research Ethics Committee of the Medical School in São José do Rio Preto and the interviewed individuals gave written post-informed consent.

The application of the questionnaire was made simultaneously in the different regions of the city in the period from January 10 to February 28 2001, by 8 professionals of the Administration and Economy University - D. Pedro II who had already worked with population surveys in this city and who were trained for the application of the research instrument. The average time for application was 25 minutes. Insomnia was defined as the presence of whatever complaint related to difficulty in going to sleep or awakening during the night or excessively early in the morning three or more times per week within the previous month, accompanied by some degree of nuisance either little, moderately or much. These criteria agree with those of the DSM III-R ${ }^{7}$ and DSM IV .

In relation to the distribution of the demographic variables we studied the gender, age, marital status, education level and economic level simultaneously to applying the questionnaire.

The ages, ranging from 18 to 90 years old, were divided in quartiles resulting in the following age groups: Group 1: 18-30; Group 2: 31-43; Group 3: $44-56$ and Group 4: $57-90$. The marital state was split in single, married (in church or common law), or previously married (separated, divorced or widowed). Education level was divided in without education, first school certificate, second school certificate and university degree. The economic levels, where the Brazilian Economic Classification Criteria were used, were grouped as A, B1, B2, C, D and E in decreasing order of spending power. This is equivalent to an average monthly income of 1600 dollars for class A, 840 dollars for class B1, 560 dollars for class B2, 290 dollars for class $C, 150$ dollars for class $D$ and 80 dollars for class E.

The questionnaire was applied during the daytime, possibly giving rise to a bias of overestimation of women. To estimate the percentage of insomniac individuals of the studied region we utilized: the proportion of women multiplied by the percentage of insomniac women among the women plus the proportion of men multi- plied by the percentage of insomniac men among the men. The proportions of men and women were obtained from the tables of IBGE - Brazilian Institute of Geography and Statistics ${ }^{5}$.

Statistical analysis - The data were input on a Microsoft Excel spreadsheet. Descriptive statistical analysis (frequency distributions, means and standard deviations) and inferential statistical analysis were performed. Comparison of two means was by student t-test and of more than two by ANOVA or Kruskal-Wallis test when indicated. A comparison of 1 proportion with a fixed value or two proportions of independent samples was made by the normal approximation test. The test for associations between qualitative variables was made by Pearson chi-squared or ANADEP9 when indicated and for the study of the association structure. A significance level, p-value, of 0.05 was adopted.

\section{RESULTS}

Of a total of 1105 individuals of the adult urban population of São José do Rio Preto, 371 (33.57\%) individuals were identified as suffering from insomnia within the month preceding the survey according to the criteria of DSM-IV and DSM-III-R. A comparison of the percentage of men and women of the sample with the population as a whole gave an estimated rate of $32 \%$ of insomnia in the adult urban population of São José do Rio Preto, Brazil. In Table 1 the distribution of insomnia, including all the subtypes, is shown according to the demographic variables.

\section{DISCUSSION}

Studying a representative sample of 1105 individuals in face-to-face interviews using a questionnaire, we evidenced an elevated prevalence of insomnia in São José do Rio Preto: $32 \%$ of the adult population complained of insomnia (of one or more subtypes) according to the DSM-III-R and DSMIV criteria. Other populational investigations also demonstrated high prevalences. Ohayon et al. ${ }^{10}$ found $36.3 \%$ insomniac individuals in the United Kingdom, utilizing the criteria of DSM-IV in interviews by telephone and in the USA Ancoli-Israel et al. ${ }^{11}$ reported $36 \%$ of the interviews as with insomnia, also in interviews by telephone but not following the DSM-IV guidelines. Another investigation in Europe ${ }^{12}$ uniting France, Germany, United Kingdom, Italy, Spain and Portugal documented a prevalence of $27.2 \%$ of insomnia based on the DSM-IV criteria by telephone. Kim et al. ${ }^{13}$ encountered a prevalence of $21.4 \%$ in the Japanese popula- 
Table 1. Distribution of insomnia (in general) in respect to demographic variables.

\begin{tabular}{|c|c|c|c|c|c|c|c|c|}
\hline & \multicolumn{3}{|c|}{ Insomniac individuals } & \multicolumn{3}{|c|}{ Non-insomniac individuals } & \multicolumn{2}{|c|}{ Total } \\
\hline & $\mathrm{N}$ & DDVI\% & DIDV\% & $\mathrm{N}$ & DDVI\% & DIDV\% & $\mathrm{N}$ & $\%$ \\
\hline \multicolumn{9}{|l|}{ Gender } \\
\hline Female & 295 & 79.51 & 35.41 & 538 & 73.30 & 64.59 & 833 & 100.00 \\
\hline Male & 76 & 20.49 & 27.94 & 196 & 26.70 & 72.06 & 272 & 100.00 \\
\hline Total & 371 & 100.00 & 33.57 & 734 & 100.00 & 66.43 & 1,105 & 100.00 \\
\hline \multicolumn{9}{|c|}{$\chi 2=5.134 \mathrm{GL}=1 \mathrm{p}=0.023$ Anadep $=\mathrm{p}: 0.022^{*}$} \\
\hline \multicolumn{9}{|l|}{ Age } \\
\hline $18-30$ years & 67 & 18.06 & 23.02 & 224 & 30.52 & 76.98 & 291 & 100.00 \\
\hline $31-43$ years & 101 & 27.22 & 37.97 & 165 & 22.48 & 62.03 & 266 & 100.00 \\
\hline $44-56$ years & 110 & 29.65 & 39.57 & 168 & 22.89 & 60.43 & 278 & 100.00 \\
\hline $57-90$ years & 93 & 25.07 & 34.44 & 177 & 24.11 & 65.56 & 270 & 100.00 \\
\hline Total & 371 & 100.00 & 33.57 & 734 & 100.00 & 66.43 & 1,105 & 100.00 \\
\hline \multicolumn{9}{|c|}{$\chi 2=21.398 \mathrm{GL}=3 \mathrm{p}=0.000$ * } \\
\hline \multicolumn{9}{|l|}{ Marital status } \\
\hline Single & 59 & 15.90 & 23.98 & 187 & 25.48 & 76.02 & 246 & 100.00 \\
\hline Previously married & 73 & 19.58 & 42.44 & 99 & 13.49 & 57.56 & 172 & 100.00 \\
\hline Married & 239 & 64.42 & 34.79 & 448 & 61.04 & 65.21 & 687 & 100.00 \\
\hline Total & 371 & 100.00 & 33.57 & 734 & 100.00 & 66.43 & 1,105 & 100.00 \\
\hline \multicolumn{9}{|c|}{$\chi 2=16.665 \mathrm{GL}=2 \mathrm{p}=0.000$ Anadep $=\mathrm{p}: 0.0002^{*}$} \\
\hline \multicolumn{9}{|l|}{ Education } \\
\hline Without education & 35 & 9.43 & 38.04 & 57 & 7.77 & 61.96 & 92 & 100.00 \\
\hline First school & 218 & 58.76 & 38.11 & 354 & 48.23 & 61.89 & 572 & 100.00 \\
\hline Second school & 81 & 21.83 & 26.38 & 226 & 30.79 & 73.62 & 307 & 100.00 \\
\hline University degree & 37 & 9.97 & 26.61 & 97 & 13.22 & 72.39 & 134 & 100.00 \\
\hline Total & 371 & 100.00 & 33.57 & 734 & 100.00 & 66.43 & 1,105 & 100.00 \\
\hline \multicolumn{9}{|c|}{$\chi 2=15.357 \mathrm{GL}=3 \mathrm{p}=0.002$ Anadep $=\mathrm{p}: 0.0001$ * } \\
\hline \multicolumn{9}{|l|}{ Economic class } \\
\hline A & 18 & 4.85 & 29.51 & 43 & 5.86 & 70.49 & 61 & 100.00 \\
\hline B1 & 35 & 9.43 & 30.17 & 81 & 11.04 & 69.83 & 116 & 100.00 \\
\hline B2 & 53 & 14.29 & 27.32 & 141 & 19.21 & 72.68 & 194 & 100.00 \\
\hline C & 170 & 45.82 & 33.86 & 332 & 45.23 & 66.14 & 502 & 100.00 \\
\hline$D / E$ & 95 & 25.61 & 40.95 & 137 & 18.66 & 59.05 & 232 & 100.00 \\
\hline Total & 371 & 100.00 & 33.57 & 734 & 100.00 & 66.43 & 1,105 & 100.00 \\
\hline \multicolumn{9}{|c|}{$\chi 2=10.133 \mathrm{GL}=4 \mathrm{p}=0.038^{*}$ Anadep $=\mathrm{p}: 0.032 *$} \\
\hline
\end{tabular}

DDVI, Distribution of the demographic variables with respect to insomnia; DIDV, Distribution of insomnia according to the demographic variables; ${ }^{*}$ statistically significant.

tion using questionnaires sent by mail without using the DSM-IV criteria and in Canada, Sutton et al. ${ }^{14}$ found a rate of $24 \%$ of insomniac individuals, without taking into account the DSM-IV guidelines. In Brazil populational researches are also being performed. The first was in the city of São Paulo, where Giglio $^{15}$ evidenced $50 \%$ of insomniac individuals in the population, considering a minimum frequency of one episode per week. In Bambui, Minas Gerais State, Rocha et al. ${ }^{16}$ classified $35.4 \%$ of the population as sufferers of insomnia and in Campo Grande, Mato Grosso do Sul, Souza et al. ${ }^{17}$ found
$19.1 \%$ of insomniac individuals, both utilizing the DSM III-R and DSM IV criteria in home visits. Other studies demonstrate lower prevalences in their populations. In Norway ${ }^{18}, 11.7 \%$ of the studied population reported insomnia, in Germany, Ohayon et al. ${ }^{19}$ encountered $6.2 \%$ of insomnia, the two surveys followed the DSM IV guidelines in interviews by telephone. In Brazil, Reimão ${ }^{20,21}$ studying indigenous populations also found a low prevalence of insomnia. Ethnical and cultural differences in the understanding and appreciation of insomnia, the form of dealing with stress, differences in habits re- 
lating to sleep hygiene are probably factors which explain the differing prevalences found in populations.

Different methodologies make the comparison between surveys difficult. These include variations in the definition of insomnia, the duration of the symptoms, the manner of applying the instrument of research (telephone, by mail or face to face interviews). We believe that in our population the method of interviewing is the best, as it did not exclude the illiterate and individuals who do not own a telephone. We faced in this research a rejection rate of $10 \%$, justified by disturbing the domestic chores due to the time required to complete the questionnaire.

Initiating the analysis of the demographic variables, there was a greater prevalence in women $(35.41 \%)$ than in men $(27.94 \%) p$-value $=0.022$, a fact that has been widely reported in both national. ${ }^{15-17}$ and international ${ }^{10,12,14,18,22,23}$ publications. This leads us to speculate about the involvement of hormonal factors. Moline ${ }^{24}$ comments that the sleep of women might be significantly affected by normal events such as pregnancy, the postpartum period, the menstrual cycle and menopause. There are no studies evaluating the effect of oral contraceptives on sleep. Nevertheless, cultural factors are also probably involved. We are aware of two studies where there were no differences in the prevalence between the genders; one was performed in Japan $^{13}$ and the other in Korea ${ }^{25}$.

When we analyzed the age of the population studied we noted that the younger adults (18-30 year-olds) were less prone ( $p$-value $=0.000)$, probably because they participate in more physical exercise and deal with fewer conflicts. Other authors emphasize the increase in the prevalence with the advance of age ${ }^{13,14,19,23}$.

The marital status also demonstrated a significant association with insomnia, with the previously married individuals (separated, divorced and widowed) the most affected ( $p$-value $=0.0002$ ) and the married subjects following close behind the singles in terms of prevalence of insomnia. $\mathrm{YeO}^{26}$ researched factors that were related with insomnia in the community in Singapore. He confirmed that stress, and in particular stress originating from the home, is the main determinant of the presence of insomnia. The greatest prevalence of insomnia in the group of previously married individuals was verified in other populational stud- ies $^{10,12,14,22}$. Bixler ${ }^{27}$ observed in Los Angeles a strong association between loneliness and insomnia, which is perhaps a common aspect in previously married individuals. Carvalho et al. ${ }^{28}$ studied personality traits of a sample of insomniac patients and found insecurity to deal with the day-to-day problems, inability to forget these problems at bedtime, worsening and maintaining the insomnia. Some works did not evidence a significant difference between the marital statuses and insomnia13,19,23.

The level of education was also analyzed, with the uneducated group and persons with little schooling significantly more associated to insomnia ( $p$ value $=0.001$ ). The individuals with less education in general also correspond to those with a lower spending power and more prone to unemployment and consequently more exposed to anguish. Other investigators also demonstrated this association ${ }^{14,23,27}$.

As the last demographic variable, we analyzed the economic class and observed a strong association with the lower social classes, that is, classes $D$ and $E$ ( $p$-value $=0.032$ ), which can be explained by the countless adverse conditions in which these individuals live. Pallesen ${ }^{18}$ encountered in Norway this same profile, however he detected that in spite of having a greater prevalence of insomnia in this group, the individuals reported less dissatisfaction with sleep than the other social classes. $\mathrm{Kim}^{13}$, on the other hand, demonstrated that in Japan there was no significant difference between the economic classes and he justified this by saying that probably in his country the socio-economic differences are less evident compared with other Westernized countries.

In conclusion, approximately one third of the adult urban population of São José do Rio Preto, Brazil presented with insomnia with the most affected being women, over 30-year-olds, previously married individuals, those with less education and a lower social class. Wide-ranging measures need to be introduced, such as training of healthcare professionals who attend public health patients, counseling of the population in relation to the importance of seeking medical assistance, divulging measures to improve the sleep hygiene and increasing specialist treatment. Other research to evaluate precipitating factors and comorbidities will be necessary for a better approach to these patients ${ }^{29}$.

Acknowledgement - We wish to express our gratitude to Professor David Andrew Hewitt for the English version. 


\section{REFERENCES}

1. Poyoner D, Tufik S.I Consenso Brasileiro de Insônia. Hypnos 2003;4:1-45.

2. Sateia MJ, Doghramji K, Hauri PJ, Morin CM. Evaluation of chronic insomnia. Sleep 2000;23:243-308.

3. Lamberg L. World Health Organization Targets Insomnia. JAMA 1997;278:1652.

4. Doghramji PP. Detection of insomnia in primary care. J Clin Psychiatry 2001;62:18-26.

5. Instituto Brasileiro de Geografia e Estatística: IBGE - Secretaria Municipal do Planejamento Gestão Estratégia - SEMPLAN; 2002.

6. Gil AC. A amostragem na pesquisa econômica. In Gil AC, (ed). Técnicas de pesquisa em economia. São Paulo: Atlas, 1988:73-93.

7. American Psychiatric Association. Manual de diagnóstico e estatística de distúrbios mentais (DSM III-R): distúrbios do sono. 3.Ed. São Paulo: Manole, 1989:318.

8. Manual Diagnóstico e Estatístico de Transtornos Mentais (DSM-IV) Transtornos do sono. 4.Ed. Porto Alegre: Artes Médicas, 1995:523.

9. Cordeiro JA. Analysis of Dependency. Relatório Técnico 48/87. Instituto de Matemática - Unicamp Campinas, 1987.

10. Ohayon MM, Caulet M, Prust RG, Guillerminault. C. DSM-IV and ICSD-90 insomnia symptoms and sleep dissatisfaction. Br J Psychiatry 1997; 171:382-388.

11. Ancoli-Israel S, Roth T. Characteristics of insomnia in the Unite States: results of the 1991 National Sleep Foundation Survey. Sleep 1999;22:347-353.

12. Ohayon MM, Roth $\mathrm{T}$. What are the contributing factors for insomnia in the general population? J Psychosomatic Res 2001;51:745-755.

13. Kim K, Uchiyama M, Okama M, Liu X, Ogihara R. An epidemiological study of insomnia among the Japanese general population. Sleep 2000;23:41-47.

14. Sutton DA, Moldofsky H, Badley EM. Insomnia and health problems in Canadians. Sleep 2001;24:665-670.

15. Giglio SBO. Estudo da ocorrência das queixas de insônia, sonolência excessiva diurna e das relativas as parassonias na população adulta da cidade de São Paulo. Tese. Escola Paulista de Medicina São Paulo, 1988.

16. Rocha FL, Guerra HL, Lima-Costa MFF. Estudo em comunidade da prevalência de insônia e fatores associados resultados do Projeto Bambuí. In Reimão R, (ed). Avanços em medicina do sono. São Paulo: Zappelini Editorial, 2001:113-126.

17. Souza IC, Magna LA, Reimão R. Insomnia and hypnotic use in Campo Grande general population, Brazil. Arq Neuropsiquiatr 2002;60:702-707.

18. Pallesen S, Nordhus IH, Nielsen GH, et al. Prevalence of insomnia in the adult Norwegian population. Sleep 2001;1:771-779.

19. Ohayon MM, Zulley J. Correlates of global sleep dissatisfaction in the German population. Sleep 2001;24:780-787.

20. Reimão R, Souza JC, Guerra HC, Gaudioso CEV. Hábitos do sono e insônia em indígenas Bororo adultos. In: Reimão R. (ED) Sono, sonho e seus distúrbios. São Paulo: Frôntis, 1999:141-142.

21. Reimão R, Souza JC, Gaudioso CEV, et al. Insônia e uso de hipnóticos em indígenas Terena. In Reimão R. (ED) Sono, sonho e seus distúrbios. São Paulo: Frôntis, 1999:143-144.

22. Chevalier H, Los F, Borchut D, et al. Evaluation of severe insomnia in the general population: results of a European multinational survey. J Psychopharmacol 1999;13:21-24.

23. Li RHY, Wing YK, Ho SC, Fong SYY. Gender differences in insomnia: a study in the Hong Kong Chinese population. J Psychosomatic Res 2002;53:601-609.

24. Moline ML, Broch L, Zak R. Sleep in women from adulthood through menopause. In Lee-Chiong TL Jr, Sateia MJ, Carskadon MA, (eds). Sleep medicine. Philadelphia: Hanley \& Belfus, 2002:105-114.

25. Ohayon MM, Hong SC. Prevalence of insomnia and associated factor in South Korea. J Psychosomatic Res 2002;53:593-600.

26. Yeo BKL, Perera IS, Kok LP, Tsoi WF. Insomnia in the community. Singapore Med J 1996;37:282-284.

27. Bixler EO, Kales A, Soldatos CR, kales JD, Healey S. Prevalence of sleep disorders in the Los Angeles metropolitan area. Am J Psychiatry 1979;136:1257-1262.

28. Carvalho LB, Lopes EA, Siva L, et al. Personality features in a sample of psychophysiological insomnia patients. Arq. Neuropsiquiatr 2003;61:588-590.

29. Marchi NSA, Características clínicas e demográficas da insônia na população adulta urbana de São José do Rio Preto, Tese (FAMERP) Faculdade de Medicina de São José do Rio Preto, 2004. 